\title{
Quality of Tteokbokki tteok prepared by adding various concentration of brown rice
}

\author{
Dong-Sun Shin ${ }^{1}$, Yeon-Mi Yoo ${ }^{2}$, Gwi-Jung $\mathrm{Han}^{2 *}$, Se-Gwan $\mathrm{Oh}^{3}$ \\ ${ }^{1}$ Petitami R\&D, Namyangju 12181, Korea \\ ${ }^{2}$ National Academy of Agricultural Science, Rural Development Adminstration, Wanju 55365, Korea \\ ${ }^{3}$ National Institute of Crop Science, Rural Development Adminstration, Wanju 55365, Korea
}

\section{흑미 첨가량을 달리한 떡볶이 떡의 품질에 관한 연구}

\author{
신동선 ${ }^{1} \cdot$ 유선미 ${ }^{2} \cdot$ 한귀정 $^{2 *} \cdot$ 오세 관 ${ }^{3}$ \\ ${ }^{1}$ (주)쁘띠아미, ${ }^{2}$ 농촌진흥청 국립농업과학원, ${ }^{3}$ 농촌진흥청 국립식량과학원
}

\begin{abstract}
The purpose of this study was to investigate the properties of tteok prepared from white (Samkwang) and brown rice (Heugseol, Heugiinju). The moisture and crude protein contents of rice were $14.89 \sim 17.15 \%$ and $4.79 \sim 6.81 \%$, respectively. The crude lipid and crude ash contents of rice were $0.48 \sim 2.66 \%$ and $0.39 \sim 1.60 \%$, respectively. The water binding capacity of Heugjinju (141.97\%) was higher than those of other rice flours. As the soaking time increased, water absorption ability was in the order of Samkwang $>$ Heugseol $>$ Heugjinju. Using a rapid visco analyser (RVA), the initial pasting temperature of Heugseol was the highest, and the peak viscosities of Heugseol were higher than those of other rice flours. The quality characteristics of Tteokbokki tteok were assessed after its preparation by adding different amounts of Heugseol and Heugjinju $(0,5,10$, and $20 \%$, w/w) content. The textural properties (hardness), of Heugseol and Heugseol measured using a texture analyzer, were greater than those of the control. Sensory preference tests revealed that $10 \%$ Heugseol and, $10 \%$ Heugjinju had the highest scores in appearance, color, and overall acceptability. The sensory test results revealed that Tteokbokki tteok prepared by addition of $10 \%$ added brown rice was the best.
\end{abstract}

Key words : brown rice, heugseol, heugjinju, tteokbokki tteok

\section{서 론}

최근 식생활의 서구화와 외식증가로 쌀 소비량이 2006년 577만 톤에서 2010년 517만 톤, 2012년 497만 톤, 2013년 484만 톤으로 계속하여 감소하고 있으며 쌀 수입개방으로 인해 쌀 재고량은 더욱 증가하고 있다. 이러한 쌀 재고량을 해결하기 위하여 쌀 소비 확대 정책으로 농림수산식품부에 서는 쌀가공산업 활성화 방안을 마련하고 가공용 쌀 소비를

*Corresponding author. E-mail : hgiaz@korea.kr Phone : 82-63-238-3551, Fax : 82-63-238-3842

Received 18 September 2015; Revised 17 February 2016; Accepted 24 February 2016.

Copyright (c) The Korean Society of Food Preservation. All rights reserved.
확대하기로 구체적인 계획을 제시하기도 하였다(1). 또한, 쌀 소비의 증대를 위하여 농촌진흥청은 가공용 쌀 품종 육성에 지속적으로 박차를 가하고 있으며, 떡류, 한과류, 쌀빵, 쌀음료 등의 다양한 쌀 가공식품에 적용하는 연구가 이루어지고 있다(2-5).

흑미는 유색미의 일종으로 본초강목에는 인체조절 기능 을 개선시키고 면역기능을 강화하며 질병예방에 효과적인 것으로 알려져 있다(6-7). 흑미는 일반 백미보다 식이섬유, 비타민, 무기질, 불포화지방산, 단백질 등의 영양성분이 우 수하며 겨층에는 flavonoid 및 anthocyanin이 많이 함유되어 있다(8). 특히, 검붉은 색을 띠는 색소에 함유되어 있는 anthocyanidin 성분(cyanidin, pheonidin, malvidin, pelargonidin, delphinidin flavylium 및 이들의 배당체)과 폴리페놀 성분은 a-tocopherol과 유사한 수준의 항산화능을 가지며 항암성, 
항동맥경화 등의 생리활성도 우수한 것으로 보고되고 있다 (9-11). 이러한 흑미는 천연항산화제로 각광을 받으며 특유 의 색과 향으로 다른 소재와 차별화로 다양한 형태의 가공 품으로 제조되면서 소비도 점차 증가하고 있다(12). 흑미의 가공에 관한 연구로는 쿠키(13), 막걸리(14), 인절미(7), 배 추김치(15), 쌀빵(16)등의 부재료로 첨가한 연구가 보고되 었다.

한편, 떡볶이는 비교적 간편한 조리법 등으로 상품화가 용이하여 지속적으로 감소하고 있는 쌀 소비량을 늘릴 수 있는 한 품목으로 활용될 수 있다. 떡볶이가 대중 상품으로 정착되면서 공장 규모의 생산 업체수도 증가하고 있는 추세 이다(17). 그러나 시판되고 있는 떡볶이 떡은 수입 밀을 $45 \%$ 사용하고 있으며, 쌀은 중국산 쌀을 사용하는 경우가 많아 떡볶이의 주 소비계층인 청소년의 영양학적 가치가 부족한 실정이다. 떡볶이 떡에 대한 연구는 주로 노화지연 및 품질 특성에 관한 연구로 변성전분 및 올리고당 시럽 첨가에 따른 노화억제 연구(18-19), 자몽종자 추출물의 산 도조절에 의한 떡볶이 떡 품질 개선(20), 가수량, 수침시간 및 증자시간에 따른 떡볶이 떡의 품질 특성(21-22) 등이 보고되었으며, 떡볶이 떡에 마늘분말(23), 전두부(24), 대 두분말(25), 인삼분말(26), 카레분말(27) 등의 부재료를 첨 가하여 품질특성을 보고한 연구가 있으나 쌀 품종별 떡볶이 용 떡의 가공적성 연구는 Shin 등(28)의 연구 외에 거의 없는 실정이다.

따라서 본 연구에서는 국내 쌀 소비확대를 위하여 가공 용으로 재배 육성된 현미로 도정한 흑설, 흑진주 등의 흑미 특성과 이를 이용한 떡복이용 떡의 가공적성이 가능한지를 파악하고자 일반성분, 수분 결합력, 수분 흡수력, 호화특성 을 조사하였으며, 흑미 떡볶이 떡을 제조하여 저장기간에 따른 색도, 물성 및 관능적 특성을 조사 하였다.

\section{재료 및 방법}

\section{실험 재료}

실험에 사용한 백미와 현미는 국립식량과학원에서 가공 용 품종으로 백미인 삼광(Samkwang, Amylose 18.52\%)과 현미 중 쌀의 부가가치 창출을 위해 육성된 흑설(Heugseol, Amylose 18.20\%) 및 흑진주(Heugjinju, Amylose 17.40\%) 등을 2011년에 재배, 수확, 건조, 저장하여 2012년에 백미와 흑미를 현미로 도정 후 3 일 보관된 것을 제공받아 공시 시료로 사용하였다. 부재료인 소금은 꽃소금(Sampio Foods, Seoul, Korea)을 농협 하나로마트에서 구입하여 사 용하였으며, 쌀가루의 제조는 분쇄기(DA505, Daesung Artlon Co., LTD., Seoul, Korea)를 이용하여 100 mesh로 분쇄한 후 본 실험을 진행하였다.

\section{흑미 떡볶이 떡 제조}

흑미 떡볶이 떡 제조는 백미인 삼광을 대조구로 하고 흑미인 흑설과 흑진주를 각각 $0,5,10$ 및 $20 \%$ 로 첨가비율을 달리하여 제조하였다. 즉, 백미 및 흑미 등의 쌀을 각각 세척하여 3 시간 동안 수침한 후 30 분 동안 물기를 제거한 다음 roll mill(KM18, Kyungchang Machine, Gyeonggi Gwangju, Korea)을 이용하여 습식방법에 의해 1,2 차 제분 하였다. 1 차 제분은 불린 쌀 무게에 소금을 $0.75 \%(\mathrm{w} / \mathrm{w})$ 넣어 롤러 간격을 $0.5 \mathrm{~mm}$ 로 맞추어 제분하였으며, 다시 불린 쌀 무게에 $20 \%(\mathrm{w} / \mathrm{w})$ 에 해당하는 물을 보충하여 롤러 의 간격을 $0.01 \mathrm{~mm}$ 로 맞추어 곱게 2 차 제분하였다. 각각 제분된 쌀가루를 시루다이식 스팀보일러(Kyungchang Machine, Gyeonggi Gwangju, Korea)를 이용하기 압력이 적 당히 올라가면 알루미늄 찜기(steamer)에 쌀가루를 넣은 다음 편편하게 펴고 면 보자기를 덮은 후 김이 오르기 시작 하면 10 분 동안 증자하였다 $\left(230^{\circ} \mathrm{C}, 0.3 \mathrm{MPa}\right)$. 증자된 것을 바로 꺼내어 멀티 떡 제조용 성형압출기(KM102, Kyungchang Machine, Machine, Gyeonggi Gwangju, Korea)에 투입하여 2 번 성형 압출한 다음 지름 $1 \mathrm{~cm}$, 길이 $30 \mathrm{~cm}$ 로 제조하였다 (28). 제조된 떡을 실온에서 약 30 분 동안 냉각시킨 후 5 $\mathrm{cm}$ 로 일정하게 자른 다음 $0,1,2$ 일 동안 상온 $\left(20^{\circ} \mathrm{C}\right)$ 에서 저장하면서 실험용 시료로 사용하였다.

\section{일반성분 및 수분결합력}

쌀가루의 일반성분 분석은 $\mathrm{AOAC}(29)$ 방법에 따라 분석 하였다. 수분 함량은 상압건조방법으로 $105^{\circ} \mathrm{C}$ 에서 건조하 여 정량하였고, 조단백질 함량은 semimicro-Kjeldahl 방법 으로 자동 단백질 분석기(Kjeltec $2400 \mathrm{AUT}$, Foss Tecator, Eden Prairie, MN, USA)로 분석하였다. 조지방 함량은 Soxhlet 추출기(SOXTEC SYSTEM HT 1043 Extraction Unit, Foss Tecator, Eden Prairie, MN, USA)를 사용하여 diethyl ether로 추출하여 정량하였으며, 조회분은 건식 회화 법으로 회화로 $\left(600^{\circ} \mathrm{C}\right.$, Box Furnace, Lindberg/Blue, Asheville, $\mathrm{NC}, \mathrm{USA}$ )에서 시료를 회화 시킨 후 남은 무게를 측정하였 고, 탄수화물은 100 에서 이들 값을 뺀 값을 표기하였다. 수분결합력 측정은 증류수 $30 \mathrm{~mL}$ 에 쌀가루 $0.5 \mathrm{~g}$ 를 넣어 1 시간 동안 교반하였다. 교반된 시료를 원심분리 $3,000 \mathrm{rpm}$, $30 \mathrm{~min}$ )한 다음 상징액은 제거하고 침전된 무게를 측정하였 으며 3회 반복 측정하여 평균값으로 나타내었다(28).

\section{수침시간에 따른 수분흡수율}

수침시간에 따른 수분흡수율 측정은 Shin 등(28)의 방법 으로 측정하였다. 먼저, 각각의 쌀을 $1 \mathrm{~g}$ 씩 시험관에 넣고 증류수 $3 \mathrm{~mL}$ 를 넣은 다음 바로 $20^{\circ} \mathrm{C}$ 항온기에 넣었다. 각각 의 시료를 $0.5,1,2,3,6,12$ 및 24시간 동안 수침시간별로 시험관을 꺼내어 물을 버리고 쌀알을 여과지에 쏟아서 쌀 표면의 물기를 제거하여 수침 전과 수침 후의 무게 증가비 
율로 수분흡수율을 나타내었다.

\section{호화특성}

쌀가루의 호화특성은 신속점도측정기(RVA-4, Newport scentific Ltd., Warriewood, Australia)를 이용하여 측정하였 다. 즉, 알루미늄 용기에 시료 $3 \mathrm{~g}$ 을 넣고 증류수 $25 \mathrm{~mL}$ 를 가하여 균일하게 분산 시켰다. 온도는 $50^{\circ} \mathrm{C}$ 로 하여 $960 \mathrm{rpm}$ 에서 1 분 동안 교반을 한 다음 $160 \mathrm{rpm}$ 으로 분당 $12^{\circ} \mathrm{C}$ 씩 온도를 올리면서 $95^{\circ} \mathrm{C}$ 까지 가열하였다. 다시 2 분 30 초간 유지시킨 후 $50^{\circ} \mathrm{C}$ 로 냉각시켜 점도를 측정하였다. 특성치 는 호화개시온도(initial pasting temperature), 최고점도(peak viscosity), 최저점도(hot viscosity), 최종점도(final viscosity), 강하점도(breakdown), 치반점도(setback) 값을 측정하였다 (30).

\section{저장기간에 따른 흑미 떡볶이 떡의 색도}

저장기간에 따른 흑설 및 흑진주를 첨가비율을 달리하여 제조한 떡볶이 떡의 색도 측청은 시료를 지름 $1.4 \mathrm{~cm}$, 길이 $5 \mathrm{~cm}$ 크기로 자른 다음 색차계(Color \& Color difference meter, Color-i-7 Macbeth, X-rite Inc., New Windsor, NY, $\mathrm{USA}$ )를 이용하여 $\mathrm{L}$ (명도), $\mathrm{a}$ (적색도) 및 $\mathrm{b}$ (황색도)를 5 회 반복 측정하여 평균값을 나타내었다(28).

\section{저장기간에 따른 흑미 떡볶이 떡의 물성}

저장기간에 따른 흑설 및 흑진주 첨가비율을 달리한 떡 볶이 떡의 물성 측정은 Texture Analyser(TA-XT2, Stable Micro System Ltd., Haslemere, UK)를 이용하여 측정하였다 (28). TPA(Texture Profile Analysis)를 이용하여 2nd bite compression test로 경도(hardness), 부착성(adhesiveness), 응 집성(cohesiveness), 씹힘성(chewiness)을 측정하였다. 이때 측정조건은 cylindrical aluminium probe(20 mm diameter)을 사용하여 pre test speed $3.0 \mathrm{~mm} / \mathrm{sec}$, test speed $1.0 \mathrm{~mm} / \mathrm{sec}$, post test speed $1.0 \mathrm{~mm} / \mathrm{sec}$ 로 하였다.

\section{저장기간에 따른 흑미 떡볶이 떡의 관능검사}

저장기간에 따른 흑설 및 흑진주 떡볶이 떡의 관능검사 는 연구원 20 명의 패널요원을 대상으로 예비실험을 통해 실험 목적 및 평가항목에 대해 잘 인지하도록 설명한 다음 평가하였다. 평가항목은 외관(appearance), 색(color), 향미 (flavor), 조직감(texture), 전반적인 기호도(overall acceptability) 로 하였으며, 평가방법은 9점 기호도법(1점: '대단히 나쁘 다', 5점: ‘보통이다', 9점: ‘대단히 좋다')으로 평가하도록 하였다. 시료번호는 랜덤화 완전 블록 실험계획법(randomized complete block design)을 적용한 세자리 난수표로 표기하였 으며 저장기간에 따른 관능검사용 시료는 일정한 크기 $(1 \times 1 \times 5 \mathrm{~cm})$ 로 자른 후 흰색 플라스틱 접시에 담아 시료를 제시하였다. 관능검사는 시료의 수가 너무 많으면 관능검
사의 정확도가 떨어지므로 두 품종 8 가지 시료를 한 품종씩 나누어 2 회 실시하였는데, 한 품종의 검사가 끝난 후 10 분 간격을 두고 다른 품종의 관능검사를 실시하였다. 한 시료 의 평가가 끝나고 다음 시료를 평가할 때는 입안을 미지근 한 물로 깨끗이 행군 다음 평가하도록 하였다.

\section{통계처리}

실험에서 얻어진 결과에 대한 통계처리는 Statistic Analysis System(Version 9.1, SAS Institute Inc, Cary, NC, USA)을 이용하여 분산분석을 실시하였으며, 유의성 검정 $(\mathrm{p}<0.05)$ 은 Duncan의 다중범위검정법(Duncan's multiple range test)을 이용하였다.

\section{결과 및 고찰}

\section{일반성분 및 수분결합력}

쌀가루의 일반성분 및 수분결합력을 측정한 결과는 Table 1에서 보는 바와 같다. 수분 함량은 백미인 삼광이 $17.15 \%$ 로 가장 높았으며 그 다음으로 현미로 도정한 흑미 인 흑설이 $15.07 \%$, 흑진주가 $14.89 \%$ 로 나타났다. 조단백질 함량은 흑설 및 흑진주가 각각 $6.09 \%, 6.81 \%$ 인 반면 삼광은 $4.79 \%$ 로 나타나 흑미가 백미보다 유의적으로 높은 경향이 었다 $(\mathrm{p}<0.05)$. 조지방 함량은 삼광이 $0.48 \%$ 로 가장 낮았고 흑설과 흑진주는 각각 $2.59 \%$ 및 $2.66 \%$ 로 유의적인 차이가 없었다(p<0.05). 조회분 함량은 흑설이 $1.60 \%$ 로 가장 높았 으며 그 다음으로 흑진주가 $1.33 \%$, 삼광이 $0.39 \%$ 로 나타났 다. 이러한 결과는 현미로 도정한 흑설의 단백질 함량이 $6.2 \%$, 흑진주가 $7.7 \%$ 이라고 한 Yang 등(4)의 보고와 현미인 흑설의 조단백질 함량이 $10.87 \%$, 조지방 함량이 $2.73 \%$ 이라 고 한 Kim 등(31)의 보고와 비교했을 때 다소 차이가 있었 다. 이는 품종, 수확시기, 재배지역, 도정방법, 저장방법, 건조방법 등에 따라 다르기 때문인 것으로 생각된다(28).

쌀가루의 수분결합력은 Table 1 에서 보는 바와 같이 삼광 이 $125.14 \%$ 로 흑설 $133.34 \%$, 흑진주 $141.97 \%$ 에 비해 낮게 나타났다. 단백질 함량이 많으면 수분결합력도 더 큰 것으 로 보이므로(32) 앞서 결과에서 흑진주의 수분결합력이 가 장 크게 나타난 것은 단백질 함량이 가장 많이 함유되어 있기 때문인 것으로 생각된다. 수분결합력은 쌀가루에 함 유된 전분의 무정형부분으로 수분의 침투 및 흡착된 수분의 양과 비례하므로 조리나 가공적성에 관련된다(33). 본 실험 의 결과 흑설과 흑진주가 삼광보다 수분결합력이 높은 것은 쌀을 제분하는 과정에서 전분의 손상도의 차이에 의한 것으 로 제분에 의해 결정구조가 파괴되어 전분의 수산기와 물분 자간에 수소결합이 쉽게 형성되기 때문인 것으로 사료된다 (28). 
Table 1. Proximate composition and water binding capacity of different cultivars of brown rice

\begin{tabular}{lccc} 
& & & (Unit: \%) \\
\hline \multicolumn{1}{c}{ Composition } & Samkwang & Heugseol & Heugjinju \\
\hline Moisture & $17.15 \pm 0.05^{\mathrm{al}}$ & $15.07 \pm 0.09^{\mathrm{b}}$ & $14.89 \pm 0.05^{\mathrm{c}}$ \\
Carbohydrate & $77.19 \pm 0.05^{\mathrm{a}}$ & $74.65 \pm 0.07^{\mathrm{b}}$ & $74.31 \pm 0.06^{\mathrm{b}}$ \\
Crude protein & $4.79 \pm 0.22^{\mathrm{c}}$ & $6.09 \pm 0.19^{\mathrm{b}}$ & $6.81 \pm 0.12^{\mathrm{a}}$ \\
Crude lipid & $0.48 \pm 0.08^{\mathrm{b}}$ & $2.59 \pm 0.03^{\mathrm{a}}$ & $2.66 \pm 0.02^{\mathrm{a}}$ \\
Crude ash & $0.39 \pm 0.10^{\mathrm{b}}$ & $1.60 \pm 0.16^{\mathrm{a}}$ & $1.33 \pm 0.09^{\mathrm{a}}$ \\
Water binding capacity & $125.14 \pm 3.38^{\mathrm{c}}$ & $133.34 \pm 6.32^{\mathrm{b}}$ & $141.97 \pm 6.85^{\mathrm{a}}$ \\
\hline${ }^{1}$ Different superscripts within a same column are significantly different by Duncan's \\
multiple range test at $\mathrm{p}<0.05$.
\end{tabular}

\section{수침시간에 따른 수분흡수율}

수침시간에 따른 쌀의 수분흡수율을 측정한 결과는 Table 2에서 보는 바와 같다. 삼광의 경우 수침초기에는 수분흡수율이 급속도로 증가하다가 3 시간까지 완만하다가 그 이후에는 변화가 없었으며 현미로 도정한 흑설과 흑진주 는 12 시간 이후에 거의 완만하다가 수침 24 시간에는 흑설 이 $32.98 \%$, 흑진주가 $30.39 \%$ 이었다. 일반적으로 쌀의 수분 흡수율은 호화정도를 예측하는 중요한 지표로 이용되며 쌀을 물에 불릴 경우 초기에는 최대 수분흡수량이 급속도로 증가하고 그 이후에는 완만하다가 평형에 도달한다고 알려 져 있다. 이러한 결과는 가공용 쌀의 수분흡수력을 측정한 결과 수침 초기에는 수분흡수율이 급속도로 증가되었으며 3 시간 까지는 완만하다가 그 이후에는 큰 변화가 없었다고 보고한 결과와 본 연구와 일치하는 경향을 보였다(28). 또
한, 현미와 같은 전곡미는 외피로 인하여 수분 침투가 느려 수분평형상태에 도달하는 시간이 백미에 비해 길다고 보고 (34)되었다. 따라서 떡볶이용 떡을 제조할 때 수침시간은 상온 $\left(20^{\circ} \mathrm{C}\right)$ 에서 백미는 3 시간, 현미는 12 시간 이상 수침하 여 제조하는 것이 바람직할 것으로 생각된다.

\section{호화특성}

품종별 쌀가루의 호화특성은 떡볶이 떡으로의 가공적성 에 적합성을 알아보는 중요한 인자가 될 수 있다. 삼광 및 흑설, 흑진주 쌀가루에 대한 호화특성을 알아보기 위해 신 속점도계(RVA)를 이용하여 분석한 결과는 Table 3에 나타 내었다. 먼저, 호화개시온도는 흑설이 $89.77^{\circ} \mathrm{C}$ 로 가장 높았 으며 그 다음으로 흑진주는 $87.57^{\circ} \mathrm{C}$, 삼광 $68.92^{\circ} \mathrm{C}$ 순으로 나타났다. 일반적인 쌀가루의 호화개시온도가 $60 \sim 65^{\circ} \mathrm{C}$ 인 것에 비해 모두 높은 값을 나타내었다. 특히, 백미보다는 현미로 도정한 흑미인 흑설과 흑진주가 더 높은 값을 나타 내어 $100 \%$ 쌀가루를 이용하여 가공하는 것은 어려울 것으 로 예상된다(28). 최고점도(peak viscosity peak), 최저점도 (hot viscosity), 최종점도(final viscosity), 강하점도(breakdown) 등의 온도에 따른 점도 변화는 모두 흑설이 가장 낮은 값을 보여 주었다. 특히, 최고점도와 최저점도의 차이인 강하점 도(breakdown)는 아밀로스 함량과 음의 상관관계를 가지며 호화 중에 열과 전단에 대한 저항성과 관계가 있는 것으로 보고되고 있으며(28) 본 실험에서는 삼광이 $742.46 \mathrm{RVU}$ 로 가장 높았고 흑설이 $253.00 \mathrm{RVU}$ 로 가장 낮았으며 흑진주는 $342.67 \mathrm{RVU}$ 로 나타났다. 노화정도를 예측할 수 있는 차반 점도(setback)에서도 백미인 삼광이 1,120.25 RVU로 가장 높았으며 현미 흑미인 흑설과 흑진주는 각각 $708.67 \mathrm{RVU}$

Table 2. Change of water absorption rate of different cultivars of brown rice at various soaking time

(Unit: \%)

\begin{tabular}{lccccccc}
\hline \multirow{2}{*}{ Cultivars } & \multicolumn{7}{c}{ Soaking time (hr) } \\
\cline { 2 - 7 } & 0.5 & 1 & 2 & 3 & 6 & 12 & 24 \\
\hline Samkwang & $15.28 \pm 0.17^{\mathrm{a} 1 \mathrm{DD} 2)}$ & $18.16 \pm 0.28^{\mathrm{aC}}$ & $29.51 \pm 0.65^{\mathrm{aB}}$ & $34.16 \pm 0.74^{\mathrm{aA}}$ & $34.68 \pm 1.13^{\mathrm{aA}}$ & $33.84 \pm 1.43^{\mathrm{aA}}$ & $34.25 \pm 1.36^{\mathrm{aA}}$ \\
Heugseo & $8.33 \pm 0.53^{\mathrm{cF}}$ & $11.80 \pm 0.83^{\mathrm{CE}}$ & $12.60 \pm 0.16^{\mathrm{cE}}$ & $16.01 \pm 0.23^{\mathrm{CD}}$ & $20.57 \pm 2.83^{\mathrm{bC}}$ & $30.43 \pm 1.18^{\mathrm{bB}}$ & $32.98 \pm 2.34^{\mathrm{bA}}$ \\
Heugjinju & $9.96 \pm 0.78^{\mathrm{bE}}$ & $15.78 \pm 0.69^{\mathrm{bD}}$ & $15.56 \pm 0.90^{\mathrm{bD}}$ & $18.93 \pm 0.89^{\mathrm{bC}}$ & $20.10 \pm 1.32^{\mathrm{bB}}$ & $30.40 \pm 4.21^{\mathrm{bA}}$ & $30.39 \pm 0.87^{\mathrm{cA}}$ \\
\hline
\end{tabular}

${ }^{1}$ Different superscripts within a same row are significantly different by Duncan's multiple range test at $p<0.05$.

${ }^{2}$ Different superscripts within a same column are significantly different by Duncan's multiple range test at $p<0.05$.

Table 3. Pasting characteristics of the different cultivars of brown rice

\begin{tabular}{|c|c|c|c|c|c|c|}
\hline \multirow[b]{2}{*}{ Cultivars } & \multicolumn{5}{|c|}{ Viscosity (RVA) } & \multirow{2}{*}{$\begin{array}{l}\text { Pasting temp } \\
\left({ }^{\circ} \mathrm{C}\right)\end{array}$} \\
\hline & $\begin{array}{l}\text { Peak viscosity } \\
\text { (cp) }\end{array}$ & $\begin{array}{l}\text { Hot viscosity } \\
\text { (cp) }\end{array}$ & $\begin{array}{l}\text { Final viscosity } \\
\text { (cp) }\end{array}$ & $\begin{array}{l}\text { Breakdown } \\
\text { (cp) }\end{array}$ & $\begin{array}{l}\text { Setback } \\
\text { (cp) }\end{array}$ & \\
\hline Samkwang & $2,348.13 \pm 38.24^{\mathrm{al})}$ & $1,603.08 \pm 62.42^{a}$ & $2,712.75 \pm 58.37^{a}$ & $742.46 \pm 36.19^{a}$ & $1,120.25 \pm 13.06^{\mathrm{a}}$ & $68.92 \pm 1.15^{\mathrm{c}}$ \\
\hline Heugseol & $719.33 \pm 12.35^{\mathrm{c}}$ & $466.33 \pm 10.28^{\mathrm{c}}$ & $1,175.00 \pm 18.07^{c}$ & $253.00 \pm 8.63^{\mathrm{c}}$ & $708.67 \pm 12.15^{\mathrm{c}}$ & $89.77 \pm 2.10^{\mathrm{a}}$ \\
\hline Heugjinju & $1,025.33 \pm 18.07^{b}$ & $682.67 \pm 12.04^{b}$ & $1,494.67 \pm 66.01^{b}$ & $342.67 \pm 13.07^{\mathrm{b}}$ & $812.00 \pm 11.02^{\mathrm{b}}$ & $87.57 \pm 1.24^{b}$ \\
\hline
\end{tabular}

${ }^{15}$ Different superscripts within a same row are significantly different by Duncan's multiple range test at $\mathrm{p}<0.05$. 
및 $812.00 \mathrm{RVU}$ 로 비슷한 수준의 값을 나타내었다.

이러한 실험결과로 미루어 보아 현미인 흑설과 흑진주는 삼광보다 호화가 힘들면서 겔이 냉각될 때 점도 변화가 적어 가공할 때 네트워크 형성이 잘 안되며 백미인 삼광은 호화가 용이하고 호화액이 냉각될 때 단단한 겔을 형성 할 수 있을 것으로 보인다(3). 따라서 현미인 흑설과 흑진주 는 단독으로 이용하기 보다는 백미 등의 다른 쌀과 혼합하 여 이용하는 것이 좋을 것으로 생각된다.

\section{저장기간에 따른 떡볶이 떡의 색도}

멥쌀인 삼광쌀을 대조구로 하고 흑미인 흑설 및 흑진주 의 첨가비율을 $0,5,10$ 및 $20 \%$ 로 달리하여 제조 한 후 떡볶이 떡의 색도 측정은 $0,1,2$ 일 동안 상온 $\left(20^{\circ} \mathrm{C}\right)$ 에서 저장하면서 색도를 측정한 결과는 Table 4와 같았다. 흑설 첨가 떡볶이 떡의 색도는 $\mathrm{L}$ 값의 경우 흑설의 첨가량이 증가 할수록 감소하였으며 저장기간에 경과함에 따라 대조구는 감소하는 반면 처리군은 모두 증가하는 경향을 보였다. 적 색도를 나타내는 $\mathrm{a}$ 값은 $\mathrm{L}$ 값과 반대 경향으로 흑설의 첨가 량이 증가할수록 증가하였고 저장기간에 따라 control는 증가하였지만 흑설의 첨가량을 달리한 처리군은 모두 조금 감소하는 경향이었다. 황색도를 나타내는 $\mathrm{b}$ 값은 control의 경우 저장기간이 경과함에 따라 증가하였으며 흑설 첨가량
과 저장기간이 증가할수록 다소 감소하였다. 흑진주를 첨 가한 떡볶이 떡의 색도도 흑설 떡볶이 떡과 비슷한 경향으 로 나타났다. 제조 직 후 $\mathrm{L}$ 값의 경우 대조구가 77.08 이었고 흑진주 첨가비율이 $5,10,20 \%$ 인 첨가군이 각각 $29.50,7.94$, 1.35 로 첨가비율이 증가할수록 감소하였고 저장기간이 증 가할수록 증가하였다. $\mathrm{a}$ 값은 흑진주 첨가비율이 증가할수 록 $\mathrm{a}$ 값은 증가하는 경향을 보였으나 $\mathrm{b}$ 값은 감소하는 경향으 로 나타났다.

이러한 본 실험의 결과와 흑미 설기떡의 연구(35)에서 색도를 측정한 결과 흑미 첨가량이 증가할수록 $\mathrm{L}$ 값 및 $\mathrm{b}$ 값 은 감소하고 $\mathrm{a}$ 값은 증가하였다는 결과와 유사하였다. 또한, 흑미 떡볶이 떡의 색은 흑설 및 흑진주쌀 자체에 함유되어 있는 안토시아닌 색소성분에서 기인된 것으로 보이며 이 색소는 열에 안정하여 떡볶이 떡 제조 후에도 색을 유지하 고 있어 항산화활성 및 심혈관 질병의 치료 등의 생리활성 기능을 나타내기 때문에 안토시아닌을 함유한 기능성 떡볶 이 떡으로서 가치가 있을 것으로 판단된다.

\section{저장기간에 따른 떡볶이 떡의 물성}

저장기간에 따른 흑설 및 흑진주의 첨가비율별 떡볶이 떡의 물성 변화는 Table 5에서 보는 바와 같다. 흑설 첨가비 율에 따른 떡볶이 떡은 경도(hardness)의 경우 흑설 첨가량

Table 4. Color value of tteokbokki tteok containing brown rice during storage at $22 \pm 1^{\circ} \mathrm{C}$

\begin{tabular}{|c|c|c|c|c|c|c|}
\hline \multirow{2}{*}{\multicolumn{2}{|c|}{ Color value }} & \multirow{3}{*}{$\begin{array}{c}\text { Storage days } \\
0\end{array}$} & \multicolumn{4}{|c|}{ Sample (\%) } \\
\hline & & & 0 & 5 & 10 & 20 \\
\hline \multirow{9}{*}{ Heugseol } & \multirow{3}{*}{$\mathrm{L}$} & & $77.08 \pm 0.74^{\mathrm{a} / \mathrm{B} 22)}$ & $34.87 \pm 1.08^{\mathrm{bAB}}$ & $21.99 \pm 2.77^{\mathrm{CB}}$ & $2.33 \pm 0.64^{\mathrm{dB}}$ \\
\hline & & 1 & $78.34 \pm 0.50^{\mathrm{aA}}$ & $33.89 \pm 1.05^{\mathrm{bB}}$ & $19.79 \pm 4.10^{\mathrm{CB}}$ & $2.73 \pm 2.45^{\mathrm{dB}}$ \\
\hline & & 2 & $73.95 \pm 1.73^{\mathrm{aC}}$ & $35.56 \pm 2.09^{\mathrm{bA}}$ & $27.85 \pm 3.05^{\mathrm{cA}}$ & $12.94 \pm 6.70^{\mathrm{dA}}$ \\
\hline & \multirow{3}{*}{$\mathrm{a}$} & 0 & $-1.88 \pm 0.14^{\mathrm{CB}}$ & $12.99 \pm 1.03^{\mathrm{bA}}$ & $17.61 \pm 3.34^{\mathrm{bA}}$ & $17.93 \pm 3.73^{a B}$ \\
\hline & & 1 & $-1.95 \pm 0.06^{\mathrm{B}}$ & $11.36 \pm 1.31^{\mathrm{bB}}$ & $18.15 \pm 5.06^{\mathrm{aA}}$ & $18.78 \pm 5.11^{\mathrm{aA}}$ \\
\hline & & 2 & $-1.77 \pm 0.07^{\mathrm{cA}}$ & $9.46 \pm 1.20^{\mathrm{bC}}$ & $10.72 \pm 1.78^{\mathrm{bB}}$ & $14.17 \pm 4.15^{\mathrm{aB}}$ \\
\hline & \multirow{3}{*}{$\mathrm{b}$} & 0 & $9.47 \pm 0.62^{\mathrm{aB}}$ & $4.69 \pm 0.62^{\mathrm{bA}}$ & $4.37 \pm 1.33^{\mathrm{bA}}$ & $3.85 \pm 1.10^{\mathrm{bA}}$ \\
\hline & & 1 & $10.31 \pm 0.28^{\mathrm{aA}}$ & $3.22 \pm 0.73^{\mathrm{cB}}$ & $4.39 \pm 2.13^{\mathrm{bA}}$ & $2.49 \pm 0.95^{\mathrm{CB}}$ \\
\hline & & 2 & $10.53 \pm 0.40^{\mathrm{aA}}$ & $2.31 \pm 0.50^{\mathrm{bC}}$ & $1.68 \pm 0.43^{\mathrm{bB}}$ & $1.86 \pm 1.80^{\mathrm{bB}}$ \\
\hline \multirow{9}{*}{ Heuginju } & \multirow{3}{*}{$\mathrm{L}$} & 0 & $77.58 \pm 0.25^{\mathrm{aB}}$ & $29.50 \pm 2.78^{\mathrm{bB}}$ & $7.94 \pm 4.46^{\mathrm{CB}}$ & $1.35 \pm 0.23^{\mathrm{dB}}$ \\
\hline & & 1 & $77.21 \pm 0.48^{\mathrm{aA}}$ & $28.50 \pm 3.02^{\mathrm{bB}}$ & $11.08 \pm 4.86^{\mathrm{CB}}$ & $2.19 \pm 0.88^{\mathrm{dB}}$ \\
\hline & & 2 & $74.06 \pm 0.07^{\mathrm{aC}}$ & $33.71 \pm 2.43^{\mathrm{bA}}$ & $17.75 \pm 8.10^{\mathrm{cA}}$ & $6.58 \pm 4.86^{\mathrm{dA}}$ \\
\hline & \multirow{3}{*}{$\mathrm{a}$} & 0 & $-1.69 \pm 0.05^{\mathrm{dB}}$ & $11.49 \pm 1.83^{\mathrm{cA}}$ & $18.02 \pm 4.18^{\mathrm{bA}}$ & $19.96 \pm 1.50^{\mathrm{aC}}$ \\
\hline & & 1 & $-1.71 \pm 0.06^{\mathrm{BB}}$ & $12.98 \pm 2.58 \mathrm{bA}$ & $17.32 \pm 5.65^{\mathrm{bA}}$ & $18.93 \pm 4.94^{a \mathrm{~B}}$ \\
\hline & & 2 & $-1.67 \pm 0.12^{\mathrm{cA}}$ & $9.34 \pm 1.02^{\mathrm{bB}}$ & $16.14 \pm 7.79^{\mathrm{aB}}$ & $18.33 \pm 4.04^{\mathrm{aA}}$ \\
\hline & \multirow{3}{*}{$\mathrm{b}$} & 0 & $9.54 \pm 0.43^{\mathrm{aB}}$ & $8.38 \pm 0.54^{\mathrm{bA}}$ & $7.42 \pm 2.45^{\mathrm{cA}}$ & $2.18 \pm 0.39^{\mathrm{dB}}$ \\
\hline & & 1 & $10.01 \pm 0.22^{\mathrm{aA}}$ & $8.55 \pm 0.67^{\mathrm{bA}}$ & $6.18 \pm 2.90^{\mathrm{cB}}$ & $3.59 \pm 1.48^{\mathrm{dA}}$ \\
\hline & & 2 & $10.23 \pm 0.36^{\mathrm{aA}}$ & $5.51 \pm 0.23^{6 \mathrm{~B}}$ & $3.25 \pm 2.56^{\mathrm{CC}}$ & $2.96 \pm 1.50^{\mathrm{d} A \mathrm{~B}}$ \\
\hline
\end{tabular}

${ }^{1}$ Different superscripts within a same row are significantly different by Duncan's multiple range test at $\mathrm{p}<0.05$.

${ }^{2}$ Different superscripts within a same column are significantly different by Duncan's multiple range test at $p<0.05$. 
Table 5. Texture properties of tteokbokki tteok containing brown rice during storage at $22 \pm 1{ }^{\circ} \mathrm{C}$

\begin{tabular}{|c|c|c|c|c|c|c|}
\hline \multirow{2}{*}{\multicolumn{2}{|c|}{ Texture properties }} & \multirow{2}{*}{$\begin{array}{l}\text { Storage } \\
\text { days }\end{array}$} & \multicolumn{4}{|c|}{ Sample (\%) } \\
\hline & & & 0 & 5 & 10 & 20 \\
\hline \multirow{12}{*}{ Heugseol } & \multirow{3}{*}{ Hardness } & 0 & $5,561.04 \pm 341.20^{\mathrm{al})(2)}$ & $5,321.15 \pm 366.58^{\mathrm{bC}}$ & $5,261.99 \pm 395.23^{\mathrm{bC}}$ & $5,212.63 \pm 240.00^{\mathrm{bC}}$ \\
\hline & & 1 & $18,912.12 \pm 740.40^{b B}$ & $17,868.49 \pm 932.69^{\mathrm{aB}}$ & $17,612.95 \pm 772.88^{6 \mathrm{~B}}$ & $14,206.64 \pm 418.45^{\mathrm{cB}}$ \\
\hline & & 2 & $37,064.15 \pm 510.42^{\mathrm{aA}}$ & $36,505.96 \pm 605.70^{\mathrm{aA}}$ & $27,160.47 \pm 446.32^{\mathrm{bA}}$ & $23,976.77 \pm 326.77^{\mathrm{cA}}$ \\
\hline & \multirow{3}{*}{ Adhesiveness } & 0 & $-1671.73 \pm 379.67^{\mathrm{cB}}$ & $-959.06 \pm 210.80^{\mathrm{bC}}$ & $-997.37 \pm 190.44^{b}$ & $-579.10 \pm 94.16^{a \mathrm{~B}}$ \\
\hline & & 1 & $-191.86 \pm 83.19^{\mathrm{aA}}$ & $-533.43 \pm 141.90^{\mathrm{bB}}$ & $-799.21 \pm 259.78^{c}$ & $-556.83 \pm 106.54^{\mathrm{dB}}$ \\
\hline & & 2 & $-5.62 \pm 3.39^{A}$ & $-1.01 \pm 0.61^{\mathrm{A}}$ & $-3.98 \pm 0.21^{\mathrm{A}}$ & $-0.70 \pm 0.80^{\mathrm{A}}$ \\
\hline & \multirow{3}{*}{ Cohesiveness } & 0 & $0.67 \pm 0.02^{\mathrm{aC}}$ & $0.65 \pm 0.01^{\mathrm{bA}}$ & $0.64 \pm 0.01^{\mathrm{cA}}$ & $0.63 \pm 0.01^{\mathrm{dA}}$ \\
\hline & & 1 & $0.60 \pm 0.02^{\mathrm{bB}}$ & $0.63 \pm 0.01^{\mathrm{aB}}$ & $0.62 \pm 0.02^{\mathrm{abA}}$ & $0.61 \pm 0.01^{\mathrm{bB}}$ \\
\hline & & 2 & $0.26 \pm 0.04^{\mathrm{bA}}$ & $0.32 \pm 0.03^{\mathrm{aC}}$ & $0.34 \pm 0.03^{\mathrm{aB}}$ & $0.34 \pm 0.01^{\mathrm{aC}}$ \\
\hline & \multirow{3}{*}{ Chewiness } & 0 & $3,647.22 \pm 208.40^{\mathrm{aC}}$ & $3,106.61 \pm 201.07^{\mathrm{bB}}$ & $3,023.92 \pm 289.85^{\mathrm{bC}}$ & $2,712.38 \pm 165.82^{\circ C}$ \\
\hline & & 1 & $9,107.91 \pm 775.89^{\mathrm{bA}}$ & $9,919.69 \pm 530.69^{\mathrm{aA}}$ & $9,303.95 \pm 545.65^{\mathrm{bA}}$ & $7,292.89 \pm 265.80^{\mathrm{cA}}$ \\
\hline & & 2 & $7,639.35 \pm 1077.62^{\mathrm{bB}}$ & $10,461.23 \pm 1166.49^{\mathrm{aA}}$ & $6,761.33 \pm 1345.33^{\mathrm{bcB}}$ & $5,890.18 \pm 604.10^{\mathrm{CB}}$ \\
\hline \multirow{12}{*}{ Heugjinju } & \multirow{3}{*}{ Hardness } & 0 & $5,861.04 \pm 341.20^{b 1)(2)}$ & $5,738.22 \pm 359.83^{\mathrm{CC}}$ & $5,702.13 \pm 491.07^{\mathrm{aC}}$ & $5,626.00 \pm 348.16^{\mathrm{bC}}$ \\
\hline & & 1 & $18,981.65 \pm 740.40^{\mathrm{cB}}$ & $17,860.24 \pm 465.70^{\mathrm{bB}}$ & $17,574.74 \pm 444.08^{\mathrm{aB}}$ & $17,212.94 \pm 533.84^{\mathrm{cB}}$ \\
\hline & & 2 & $38,213.64 \pm 112.82^{\mathrm{aA}}$ & $33,596.29 \pm 222.80^{\mathrm{bA}}$ & $31,818.17 \pm 470.88^{\mathrm{aA}}$ & $31,198.88 \pm 468.01^{\mathrm{cA}}$ \\
\hline & \multirow{3}{*}{ Adhesiveness } & 0 & $-1,671.73 \pm 379.67^{\mathrm{bB}}$ & $-1,239.39 \pm 333.38^{\mathrm{aC}}$ & $-1,007.80 \pm 283.43^{\mathrm{aB}}$ & $-1,189.59 \pm 85.63^{\mathrm{aB}}$ \\
\hline & & 1 & $-191.86 \pm 83.19^{\mathrm{aA}}$ & $-386.64 \pm 184.53^{\mathrm{bB}}$ & $-153.69 \pm 94.73^{\mathrm{aA}}$ & $-386.61 \pm 83.18^{\mathrm{bA}}$ \\
\hline & & 2 & $-5.62 \pm 3.39^{\mathrm{aA}}$ & $-25.80 \pm 55.06^{\mathrm{aA}}$ & $-1.82 \pm 0.84^{\mathrm{aA}}$ & $-230.52 \pm 424.53^{\mathrm{aA}}$ \\
\hline & \multirow{3}{*}{ Cohesiveness } & 0 & $0.67 \pm 0.02^{\mathrm{abC}}$ & $0.66 \pm 0.02^{\mathrm{bA}}$ & $0.68 \pm 0.01^{\mathrm{aA}}$ & $0.65 \pm 0.01^{\mathrm{cA}}$ \\
\hline & & 1 & $0.60 \pm 0.02^{\mathrm{bB}}$ & $0.62 \pm 0.02^{\mathrm{bB}}$ & $0.65 \pm 0.01^{\mathrm{aB}}$ & $0.61 \pm 0.01^{\mathrm{bB}}$ \\
\hline & & 2 & $0.26 \pm 0.04^{\mathrm{cA}}$ & $0.38 \pm 0.03^{\mathrm{aC}}$ & $0.31 \pm 0.03^{\mathrm{bC}}$ & $0.37 \pm 0.03^{\mathrm{aA}}$ \\
\hline & \multirow{3}{*}{ Chewiness } & 0 & $3,647.22 \pm 208.40^{\mathrm{bC}}$ & $3,242.35 \pm 239.94^{\mathrm{CC}}$ & $4,131.65 \pm 314.17^{\mathrm{aC}}$ & $3,529.80 \pm 195.65^{\mathrm{bC}}$ \\
\hline & & 1 & $9,107.91 \pm 775.89^{\mathrm{cA}}$ & $10,974.97 \pm 430.83^{\mathrm{bA}}$ & $14,295.69 \pm 271.99^{\mathrm{aA}}$ & $9,338.68 \pm 441.68^{\mathrm{cA}}$ \\
\hline & & 2 & $7,639.35 \pm 177.62^{\mathrm{cB}}$ & $9,993.20 \pm 887.68^{\mathrm{aB}}$ & $9,105.91 \pm 330.10^{\mathrm{abB}}$ & $8,633.39 \pm 981.32^{\mathrm{bcB}}$ \\
\hline
\end{tabular}

${ }^{1)}$ Different superscripts within a same row are significantly different by Duncan's multiple range test at $\mathrm{p}<0.05$.

${ }^{2)}$ Different superscripts within a same column are significantly different by Duncan's multiple range test at $\mathrm{p}<0.05$.

이 증가할수록 낮게 나타났으며 대조구와 흑설을 첨가한 처리군 모두에서 저장 1 일째에는 약 3 배 이상 증가하여 즉석용으로는 상품가치가 떨어졌다. 떡볶이용 용도로만 본 다면 상품가치가 떨어진다고는 볼 수 없지만, 조리 시 끓이 는 시간이 길어져서 편이성이 감소되고 조리 후의 물성의 변화가 달라질 것으로 예상되어 이에 대한 연구가 더 필요 할 것으로 생각된다. 부착성(adhesiveness), 응집성(cohesiveness) 및 씹힘성(chewiness)도 경도(hardness)와 비슷한 경향으로 나타났다. 흑진주 첨가비율에 따른 떡볶이 떡의 물성변화 도 흑설 떡볶이 떡과 비슷한 경향으로 나타났다. 경도의 경우 대조구인 멥쌀삼광은 5,861.04로 가장 높았고 흑미인 흑진주를 5,10 및 $20 \%$ 첨가한 첨가군에서는 각각 $5,738.22$, $5,702.13$ 및 5,626.00으로 흑진주 첨가비율이 증가할수록 경도는 낮게 나타났다. 저장기간이 경과함에 따라 대조구 와 모든 처리군에서 유의적으로 증가하였으며 부착성, 응 집성 및 씹힘성도 경도와 비슷한 경향을 나타내었다 $(\mathrm{p}<0.05)$. 흑진주의 첨가량은 $20 \%$ 까지도 가공이 가능할 것 으로 보인다. 이러한 결과는 흑미가 멥쌀에 비해 아밀로오 스 함량이 낮고 식이섬유 함량이 4.0 5.9\%로 높았으며 흑미 설기떡의 품질특성에서 흑미 첨가량이 증가할수록 경도가 감소했다는 결과(35)와 비슷한 경향을 나타내었다. 따라서 흑설은 가공용 쌀로 육성된 것으로 떡볶이 떡으로서 가공 적성은 가능하나 떡의 물성을 더 보완해야하며 저장기간을 연장할 수 있는 많은 연구가 진행되어야 한다고 생각된다.

일반적으로 쌀의 수분 함량과 단백질 함량은 밥맛을 결 정하는 중요한 인자로 특히 단백질 함량이 높은 쌀은 낮은 쌀에 비하여 더 단단하기 때문에 경도에 영향을 미친다고 알려져 있다. 이것은 전분입자 주변에 단백질 층이 형성되 어 취반 후 밥의 점성 및 탄성을 저하시키고 전분의 호화 특성에 직접적으로 영향을 주기 때문인 것으로 보고되고 있다(36). 본 실험 결과에서 단백질 함량이 흑설과 흑진주는 $6 \%$ 이상인 반면 삼광은 단백질 함량이 $6 \%$ 이하로 나타나 
물리적 성질과 가공적성에 영향을 미칠 것으로 생각된다. 또한, 단백질 함량이 경도에 미치는 영향을 고려한다면 흑 미를 현미가 아닌 백미로 도정하는 것도 하나의 방법으로 고려해 볼 필요가 있지만, 건강측면에서 백미에 현미로 도정 한 흑미를 혼합하여 제조하는 것이 바람직할 것으로 보인다.
경우 제조 직 후 흑진주 $10 \%$ 첨가 떡볶이 떡이 5.90 으로 가장 선호도가 높았고 흑설 $5 \%$ 첨가 떡볶이가 4.80 으로 가 장 선호하지 않는 것으로 나타났다. 저장기간이 경과함에 따른 외관의 선호도는 흑설 $10 \%$ 첨가 떡볶이 떡으로 나타 났다. 색도는 외관의 기호도와 비슷한 양상으로 흑설 $10 \%$

Table 6. Sensory characteristics of tteokbokki tteok containing brown rice during storage at $22 \pm 1^{\circ} \mathrm{C}$

\begin{tabular}{|c|c|c|c|c|c|c|}
\hline & \multirow{2}{*}{ Items } & \multirow{2}{*}{$\begin{array}{c}\text { Storage } \\
\text { days }\end{array}$} & \multicolumn{4}{|c|}{ Sample (\%) } \\
\hline & & & 0 & 5 & 10 & 20 \\
\hline \multirow{15}{*}{ Heugseol } & \multirow{3}{*}{ Appearance } & 0 & $5.30 \pm 0.82^{\mathrm{abl} 1 \mathrm{~A} 2)}$ & $4.80 \pm 1.14^{\mathrm{bA}}$ & $5.90 \pm 0.57^{\mathrm{aA}}$ & $5.10 \pm 1.52^{\mathrm{abA}}$ \\
\hline & & 1 & $4.90 \pm 0.32^{\mathrm{cA}}$ & $5.20 \pm 1.03 \mathrm{cA}$ & $6.30 \pm 0.67^{\mathrm{aA}}$ & $5.40 \pm 1.84^{\mathrm{acA}}$ \\
\hline & & 2 & $5.60 \pm 0.97^{\mathrm{aA}}$ & $5.30 \pm 1.34^{\mathrm{aA}}$ & $6.00 \pm 1.41^{\mathrm{aA}}$ & $4.90 \pm 1.29^{\mathrm{aA}}$ \\
\hline & \multirow{3}{*}{ Color } & 0 & $5.10 \pm 0.88^{\mathrm{aAB}}$ & $4.70 \pm 1.25^{\mathrm{aA}}$ & $5.90 \pm 1.20^{\mathrm{aA}}$ & $5.30 \pm 1.64^{\mathrm{aA}}$ \\
\hline & & 1 & $4.70 \pm 0.48^{\mathrm{aA}}$ & $4.90 \pm 1.37^{\mathrm{aA}}$ & $5.90 \pm 1.20^{\mathrm{aA}}$ & $5.20 \pm 1.69^{\mathrm{aA}}$ \\
\hline & & 2 & $5.60 \pm 1.17^{\mathrm{aA}}$ & $5.40 \pm 1.71^{\mathrm{aA}}$ & $5.70 \pm 0.95^{\mathrm{aA}}$ & $4.70 \pm 1.34^{\mathrm{aA}}$ \\
\hline & \multirow{3}{*}{ Flavor } & 0 & $4.90 \pm 0.88^{\mathrm{aA}}$ & $4.80 \pm 0.92^{\mathrm{aA}}$ & $4.80 \pm 1.03^{\mathrm{aA}}$ & $5.50 \pm 1.65^{\mathrm{aA}}$ \\
\hline & & 1 & $4.90 \pm 0.32^{\mathrm{bA}}$ & $4.90 \pm 0.74^{\mathrm{bA}}$ & $5.80 \pm 1.23^{\mathrm{abA}}$ & $5.90 \pm 1.20^{\mathrm{aA}}$ \\
\hline & & 2 & $4.80 \pm 1.03^{\mathrm{aA}}$ & $5.00 \pm 0.67^{\mathrm{aA}}$ & $5.80 \pm 1.40^{\mathrm{aA}}$ & $5.30 \pm 0.95^{\mathrm{aA}}$ \\
\hline & \multirow{3}{*}{ Texture } & 0 & $5.10 \pm 0.74^{\mathrm{aA}}$ & $5.20 \pm 0.92^{\mathrm{aA}}$ & $5.40 \pm 1.07^{\mathrm{aA}}$ & $5.50 \pm 1.96^{\mathrm{aB}}$ \\
\hline & & 1 & $5.00 \pm 0.82^{\mathrm{bA}}$ & $4.70 \pm 0.95^{\mathrm{bAB}}$ & $6.10 \pm 0.99 \mathrm{aA}$ & $7.00 \pm 1.25^{\mathrm{aA}}$ \\
\hline & & 2 & $3.70 \pm 0.67^{\mathrm{bB}}$ & $4.00 \pm 1.41^{\mathrm{bB}}$ & $5.50 \pm 1.65^{\mathrm{aA}}$ & $5.90 \pm 0.88^{\mathrm{a} A \mathrm{~B}}$ \\
\hline & \multirow{3}{*}{$\begin{array}{c}\text { Overall } \\
\text { acceptability }\end{array}$} & 0 & $5.40 \pm 0.97^{\mathrm{zA}}$ & $5.40 \pm 1.07^{\mathrm{aA}}$ & $5.40 \pm 1.07^{\mathrm{aB}}$ & $5.10 \pm 1.29^{a B}$ \\
\hline & & 1 & $4.90 \pm 0.57^{\mathrm{cAB}}$ & $5.20 \pm 1.03^{\mathrm{bcAB}}$ & $6.50 \pm 0.79^{\mathrm{aA}}$ & $6.30 \pm 1.06^{\mathrm{aA}}$ \\
\hline & & 2 & $4.20 \pm 1.03^{a \mathrm{~B}}$ & $4.60 \pm 1.65^{\mathrm{aB}}$ & $5.50 \pm 1.58^{\mathrm{aB}}$ & $5.30 \pm 1.06^{\mathrm{aAB}}$ \\
\hline \multirow{15}{*}{ Heugjinju } & \multirow{3}{*}{ Appearance } & 0 & $5.50 \pm 0.85^{\mathrm{aA}}$ & $5.20 \pm 1.23^{\mathrm{abA}}$ & $6.20 \pm 0.97^{\mathrm{aA}}$ & $4.30 \pm 1.70^{\mathrm{bA}}$ \\
\hline & & 1 & $5.00 \pm 0.67^{\mathrm{aA}}$ & $5.70 \pm 1.49^{\mathrm{aA}}$ & $5.70 \pm 1.64^{\mathrm{aA}}$ & $5.30 \pm 1.77^{\mathrm{aA}}$ \\
\hline & & 2 & $5.10 \pm 0.74^{\mathrm{aA}}$ & $5.20 \pm 1.32^{\mathrm{aA}}$ & $5.70 \pm 1.89^{\mathrm{aA}}$ & $4.50 \pm 1.96^{\mathrm{aA}}$ \\
\hline & \multirow{3}{*}{ Color } & 0 & $5.50 \pm 0.85^{\mathrm{abA}}$ & $5.10 \pm 1.29^{\mathrm{abA}}$ & $6.10 \pm 0.88^{\mathrm{aA}}$ & $4.50 \pm 1.96^{\mathrm{bA}}$ \\
\hline & & 1 & $5.00 \pm 0.82^{\mathrm{aA}}$ & $5.60 \pm 1.65^{\mathrm{aA}}$ & $6.10 \pm 1.79^{\mathrm{aA}}$ & $5.30 \pm 2.00^{\mathrm{aA}}$ \\
\hline & & 2 & $5.30 \pm 0.82 \mathrm{aA}$ & $5.30 \pm 1.06^{\mathrm{aA}}$ & $5.50 \pm 1.90^{\mathrm{aA}}$ & $3.80 \pm 1.55^{\mathrm{bA}}$ \\
\hline & \multirow{3}{*}{ Flavor } & 0 & $5.00 \pm 0.82^{\mathrm{aA}}$ & $5.90 \pm 0.88^{\mathrm{aA}}$ & $5.60 \pm 1.07^{\mathrm{aA}}$ & $5.60 \pm 1.65^{\mathrm{aA}}$ \\
\hline & & 1 & $4.60 \pm 0.70^{\mathrm{bA}}$ & $5.20 \pm 0.79^{\mathrm{abA}}$ & $5.90 \pm 1.45^{\mathrm{aA}}$ & $5.70 \pm 1.16^{\mathrm{aA}}$ \\
\hline & & 2 & $4.90 \pm 0.74^{\mathrm{aA}}$ & $5.10 \pm 1.66^{\mathrm{aA}}$ & $5.10 \pm 1.20^{\mathrm{aA}}$ & $5.70 \pm 1.49^{\mathrm{aA}}$ \\
\hline & \multirow{3}{*}{ Texture } & 0 & $5.50 \pm 1.08^{\mathrm{aA}}$ & $5.00 \pm 1.25^{\mathrm{aA}}$ & $5.20 \pm 1.23^{\mathrm{aA}}$ & $5.40 \pm 1.70^{\mathrm{aA}}$ \\
\hline & & 1 & $3.80 \pm 0.92^{c^{\mathrm{B}}}$ & $4.20 \pm 0.92^{\mathrm{bcAB}}$ & $5.20 \pm 1.62^{\mathrm{abA}}$ & $5.70 \pm 1.34^{\mathrm{aA}}$ \\
\hline & & 2 & $3.00 \pm 1.33^{\mathrm{bB}}$ & $3.40 \pm 1.17^{\mathrm{bB}}$ & $3.30 \pm 1.57^{\mathrm{bB}}$ & $5.10 \pm 2.02^{\mathrm{aA}}$ \\
\hline & \multirow{3}{*}{$\begin{array}{c}\text { Overall } \\
\text { acceptability }\end{array}$} & 0 & $5.20 \pm 0.97^{\mathrm{aA}}$ & $5.30 \pm 1.07^{\mathrm{aA}}$ & $5.70 \pm 1.07^{\mathrm{aA}}$ & $5.00 \pm 1.29^{\mathrm{aA}}$ \\
\hline & & 1 & $4.40 \pm 0.97^{\mathrm{bA}}$ & $5.30 \pm 1.16^{\mathrm{abA}}$ & $5.80 \pm 1.40^{\mathrm{aA}}$ & $5.60 \pm 0.97^{\mathrm{aA}}$ \\
\hline & & 2 & $3.30 \pm 1.16^{\mathrm{bB}}$ & $4.30 \pm 1.49^{\mathrm{abA}}$ & $5.10 \pm 1.99^{\mathrm{abB}}$ & $4.90 \pm 1.73^{\mathrm{aA}}$ \\
\hline
\end{tabular}

${ }^{1)}$ Different superscripts within a same row are significantly different by Duncan's multiple range test at $\mathrm{p}<0.05$.

${ }^{2)}$ Different superscripts within a same column are significantly different by Duncan's multiple range test at $p<0.05$.

저장기간에 따른 떡볶이 떡의 관능검사

저장기간에 따른 흑설 및 흑진주 떡볶이 떡의 관능적 특성으로 기호도를 조사한 결과는 Table 6에서 보는 바와 같다. 먼저 흑설 첨가 떡볶이 떡의 관능검사에서 외관의
첨가군이 5.90로 가장 선호하는 것으로 나타났다. 향미와 질감의 경우에는 흑설 $20 \%$ 첨가군이 흑설 $10 \%$ 첨가군 보다 더 높은 점수를 받아 가장 선호하는 것으로 나타났다. 전반 적인 기호도는 제조 직 후 보다 저장 1 일째 더 선호도가 
높았는데 저장 1 일째 흑설 첨가비율에 따라 $0,5,10$ 및 $20 \%$ 가 각각 $4.90,5.20,6.50,6.30$ 로 점수를 받아 흑설 첨가 비율이 $10 \%>20 \%>5 \%>0 \%$ 순으로 선호하는 것으로 나타났다. 저장기간에 경과함에 따라 낮은 점수를 받았지 만 시료간의 유의적인 차이는 나타나지 않았다 $(\mathrm{p}<0.05)$. 흑진주 첨가비율별 떡볶이 떡의 관능적 기호도는 평가항 목에서 전체적인 기호도는 제조 직후 대조구와 처리군 모두 에서 5.0 이상의 점수를 받았으며, 특히, 흑진주 $10 \%$ 첨가군 이 5.70으로 가장 높은 점수를 받았다. 저장기간이 증가할 수록 흑진주 첨가비율을 달리한 처리군보다 대조구가 더 낮은 점수를 받았다. 외관과 색은 제조 직후 저장 1 일 및 저장 2 일 모두 흑진주 $10 \%$ 첨가군이 각각 $6.20,6.10$ 으로 가장 높게 나타났으며 흑진주 $20 \%$ 첨가군이 가장 낮게 나타났다. 향미는 제조 직후에는 흑진주 $5 \%$ 첨가군, 저장 1 일째는 $10 \%$ 첨가군, 저장 2 일에는 흑진주 $20 \%$ 첨가군이 높은 점수를 받았다. 질감은 제조 직후 대조구가 5.50으로 가장 높았으나 저장기간이 경과함에 따라 흑진주 많이 첨가 된 $20 \%$ 첨가군이 선호도가 가장 높았다. Doo와 Shin (35)의 보고에서 흑미 설기떡의 관능적 기호도 평가에서 대조구 보다 선호도가 적었다는 결과와 본 실험 결과와는 다르게 나타났다. 전반적으로 흑진주 첨가량이 증가할수록 제조 직 후 보다 하루 정도 지난 후의 말랑말랑한 질감을 더 선호하는 것으로 나타났다. 떡볶이용 용도로 본다면 조리 후의 품질특성 및 관능적 기호도 평가도 필요할 것으로 보인다.

따라서, 흑미의 적절한 첨가는 맛, 향, 냄새, 질감 등의 관능적 기호도에 영향을 줄 것으로 생각되며 떡볶이 떡의 적절한 흑미 첨가량은 10 20\%가 적당할 것으로 생각된다. 앞으로 좀 더 신뢰성이 높은 결과를 얻기 위하여 흑미 떡볶 이 떡을 제조하여 일반인을 대상으로 한 소비자 기호도 조사가 더 필요할 것으로 보인다.

\section{요 약}

쌀 소비확대를 위하여 가공용으로 재배 육성된 흑미의 특성과 떡복이용 떡에 가공적성이 가능한지를 파악하고자 일반성분, 수분 결합력, 수분 흡수력, 호화특성을 조사하였 으며, 삼광을 대조구로 하여 흑설, 흑진주 떡볶이 떡을 제조 하여 저장기간에 따른 색도, 물성 및 관능적 특성을 조사 하였다. 일반성분을 분석한 결과 수분이 $14.89 ~ 7.15 \%$, 조단 백질이 $4.79 \sim 6.81 \%$, 조지방이 $0.48 \sim 2.66 \%$, 조회분이 $0.39 \sim 1.60 \%$ 로 나타났다. 특히, 흑진주는 조단백질과 조지 방 함량이 가장 높았고 삼광이 조단백질함량이 가장 낮게 나타났다. 수분결합력은 흑진주가 가장 높았고 그 다음으 로 흑설이 높은 것으로 나타났다. 수침시간에 따른 수분흡 수율은 수침 초기에 흡수속도가 높았으며 대조구인 삼광은
수침 3시간, 현미로 도정한 흑미는 12 시간 까지는 완만하게 증가하다가 그 이후에는 거의 변화가 없어 평형에 도달하였 다. 호화특성에서 호화개시온도는 흑설이 가장 높았으며 최고점도(peak viscosity peak), 최저점도(hot viscosity), 최 종점도(final viscosity), 강하점도(breakdown) 등의 온도에 따른 점도 변화는 흑설이 가장 낮은 값을 보여 주었다. 차반 점도(setback)는 백미인 삼광이 가장 높았으며 현미 흑미인 흑설과 흑진주는 비슷한 수준의 값을 나타내었다. 흑미 떡 볶이 떡의 색도는 흑미 첨가량이 증가할수록 $\mathrm{L}$ 값 및 $\mathrm{b}$ 값은 감소하고 $\mathrm{a}$ 값은 증가하였으며 저장기간이 경과함에 따라 $\mathrm{L}$ 값은 증가한 반면 $\mathrm{a}$ 값 및 $\mathrm{b}$ 값은 감소하는 경향을 보였다. 흑미 떡볶이 떡의 물성변화는 흑미의 첨가량이 증가함에 따라 경도, 응집성, 씹힘성은 감소하는 반면 부착성은 증가 하였으며 저장기간이 경과함에 따라 경도의 경우 증가하는 경향을 보였다. 또한, 관능적 특성의 전반적인 기호도 조사 에서 흑미 $10 \%$ 첨가군을 가장 선호하는 것으로 나타났지만 $20 \%$ 첨가군과의 유의적인 차이는 없었다 $(\mathrm{p}<0.05)$. 따라서, 떡볶이 떡 제조 시 적절한 흑미 첨가량은 $10 ~ 20 \%$ 가 적당 할 것으로 보이며 흑미 첨가가 관능적 기호도에 좋은 영향 을 줄 것으로 기대된다.

\section{감사의 글}

본 연구는 농촌진흥청 연구사업(PJ0118172016)의 지원 에 의해 이루어진 것임.

\section{References}

1. Food Journal (2012) Ministry for Food, Agriculture, Forestry and Fisheries 2012 Food news. Food Journal, Seoul, Korea, p 175, p 118

2. Song YC, Lim SJ, Lee JS, Kim HY, Yeo US, Park NB, Kwak DY, Kang JR, Yang SJ, Hwang HG, Oh BG, Moon HP, Lim MS (2008) A new high amylose rice variety "Goamibyeo". Korean J Breed Sci, 40, 447-451

3. Choi SY, Shin MS (2009) Properties of rice flours prepared from domestic high amylose rices. Korean $\mathbf{J}$ Food Sci Technol, 41, 16-20

4. Yang CI, Choi YH, Lee SB, Lee KS, Lee JH, Hong HC, Kim HY, Shin YS, Hwang HG, Yang SJ, Jung OY, Jeon YH, Oh MG, Kim MK, Lee JH, Cho YC, Lee JI, Hwang KH, Kim YG, Lee YT (2012) A new black pericarp and processing soft rice cultivar 'Heugseol'. Korean J Breed Sci, 44, 35-40

5. Cho JH, Park NB, Song YC, Yeo US, Ha UG, Jung 
KH, Lee JY, Lee JH, Kim CS, Kwak DY, Kim SY, Yi GH, Oh SH, Kang HW, Ahn JG (2012) 'Saegyejinmi': Multiple disease resistance and mid-late maturing tongil type rice cultivar. Korean J Breed Sci, 44, 611-616

6. Cho JA, Cho HJ (2000) Quality properties of injulmi made with black rice. Korean J Soc Food Sci, 16, 226-131

7. Jung DS, Eun JB (2003) Rheological properties of dough added with black rice flour. Korean J Food Sci Technol, $35,38-43$

8. Kong SH, Choi YM, Lee SM, Lee JS (2008) Antioxidant compounds and antioxidant activities of the methanolic extracts from milling fractions of black rice. J Korean Soc Food Sci Nutr, 37, 815-819

9. Velioglu YS, Mazza G, Gao L, Oomah BD (1998) Antioxidant activity and total phenolics in selected fruits, vegetables and grain products. J Agricultural Food Chemistry, 46, 4113-4117

10. Ling WH, Wang LL, Ma J (2002) Supplementation of the black rice outer layer fraction to rabbits decreases antioxidant status. J Nutr, 132, 20-26

11. Chiang AN, Wu HL, Yeh HI, Chu CS, Lin HC, Lee WC (2006) Antioxidant effects of black rice extract through the induction of superoxide dismutase and catalase activities. Lipids, 41, 797-803

12. Kim YH, Lee YJ, Park SO, Lee SJ, Lee OH (2013) Antioxidant compounds and antioxidant activities of fermented black rice and its fractions. Korean J Food Sci Technol, 45, 262-266

13. Moon BK, Kim EA, Park MS, Lee DK, Lee MS, Choi BR (2007) Quality characteristics of cookies with black rice powder. J Hum Ecol, 26, 21-28

14. Kim OS, Park SS, Sung JM (2012) Antioxidant activity and fermentation characteristics of traditional black rice wine. J Korean Soc Food Sci Nutr, 41, 1693-1700

15. Mo EK, Kim SM, Yang SA, Jegal SA, Choi YS, Ly SY, Sung CK (2010) Properties of baechu kimchi treated with black rice water extract. Korean J Food Preserv, $17,50-57$

16. Im JS, Lee YT (2010) Quality characteristics of rice bread substituted with black rice flour. J East Asian Soc Dietary Life, 20, 903-908

17. Lee JH (2008) Study on the quality characteristics of green rice Garaedduk. Ph D Thesis, Sejong University, Korea, p 30-38

18. Park JW, Park HJ, Song JC (2003) Suppression effect of maltitol on retrogradation of Korean rice cake (Karedduk). Korean J Food Nutr, 32, 175-180
19. Shin WC, Park HJ, Song JC (2006) Optimization of modified starches on retrogradation of Korean rice cake (Garaeduk). Korean J Food Nutr, 19, 279-287

20. Kang HJ, Park JD, Lee HY, Kum JS (2013) Effect of grapefruit seed extracts and acid regulation agents on the qualities of Topokkidduk J Korean Soc Food Sci Nutr, 42, 948-956

21. Kang HJ, Lee JK, Lim JK (2012) Quality characteristics of Topokki Garaedduk with different moisture ratios. J Korean Soc Food Sci Nutr, 41, 561-565

22. Yu JH, Han GH (2004) Quality characteristics of rice cake (Karedduk) with different soaking and steaming time. Korean J Soc Food Cook Sci, 20, 630-636

23. Kim MS, Park JD, Lee HY, Park SS, Kum JS (2012) Changes in the quality characteristics of Tpokkidduk prepared with garlic powder. J Korean Soc Food Sci Nutr, 41, 982-987

24. Lee JK, Jeong JH, Lim JK (2012) Quality characteristics of Topokkidduk with respect to added whole soybean curd (Chun-tofu) by different storage time. Korean J Food Cook Sci, 28, 111-121

25. Kang HJ, Park JD, Lee HY, Kum JS (2012) Quality characteristics of Topokkidduk added with soybean flour. Korean J Food Preserv, 19, 688-695

26. Lee JK, Jeong JH, Lim JK (2011) Quality characteristics of Topokki Garaedduk added with ginseng powder. J Korean Soc Food Sci Nutr, 40, 426-434

27. Ahn JW (2009) Properties of rice cakes for Topokki with curry powder. Korean J Food Cookery Sci, 25, 467-473

28. Shin DS, Kim HY, Hong HC, Oh SG, Yoo SM (2014) The effects on the quality of Tteokbokki tteok by different types cultivars of rice. Korean J Food Cookery Sci, 30, 271-277

29. AOAC (1995) Official Methods of Analysis of AOAC International. 16th ed. Method 920.39, 935.29, 942.05, 984.13. Association of Official Analytical Communities, Arlington, VA, USA

30. AACC (2000) International Approved Methods of the AACC, 11th ed. Method 61-02. Association of Cereal Chemists, St. Paul, MN, USA

31. Kim HW, Oh SK, Lee JH, Yoon MR, Kim DJ, Choi IS, Kim JG, Lee JS (2013) Evaluation of antioxidant and cancer cell growth inhibition activities of red rice and black rice. Korean J Food Preserv, 20, 834-839

32. Dogan SF, Sahin S, Sumnu G (2005) Effects of soy and rice flour addition on batter rheology and quality of deep-fat fried chicken nugget. J Food Eng, 71, 127-132 
33. Kim RY, Kim CS, Kim HI (2009) Physicochemical properties of non-waxy rice flour affected by grinding methods and steeping times. J Korean Soc Food Sci Nutr, 38, 1076-1083

34. Lee YT (2013) Properties of normal and glutinous black rice flours prepared by different milling methods. Food Eng Prog, 17, 339-345
35. Doo HJ, Shin JY (2010) Quality characteristics of black rice Sulgiddeok with black garlic powder. Korean J Food Cookery Sci, 26, 677-684

36. Juliano BO (1985) Polysaccharides, protein, and lipids of rice. In rice chemistry and technology. Juliano BO (ed). Am Assoc Cereal Chem, St. Paul, MN, USA, p 59 